\title{
Transglutaminase-mediated restoration of historic silk and its ageing resistance
}

Zhanyun Zhu' ${ }^{1,2}$, Liu Liu ${ }^{1,2}$ and Decai Gong ${ }^{1,2^{*}}$

\begin{abstract}
Introduction: Transglutaminase-mediated polymerization, unlike the traditional restoration methods based on the application of synthetic polymers, has proved to be a potential strategy in the restoration of historic silk. In the present study, the treatment process has been adapted to satisfy the needs of consolidating historic silk fabrics in various cases. Artificially aged (dry thermal ageing) silk samples were restored using this method. The effects of the reaction on silk fibers were investigated by tensile tests, colour difference tests, scanning electron microscopy and FT-IR. The ageing resistance of the restored samples was evaluated.

Results: The results showed that tensile strength, elongation rate at breakage and micro morphology of the silk samples were remarkably improved without significant colour difference after restoration. FT-IR spectroscopy confirmed the existence of transglutaminase-induced biopolymers in the restored silk samples and demonstrated that the transglutaminase-mediated restoration did not change the basic structure of silk protein. The ageing resistance of the restored samples evaluated using standard methods ensured that the treatment would not introduce any long term problems. The method was then applied to genuine historic silk fabrics and achieved the desired results.
\end{abstract}

Conclusions: From the results of this study, the effectiveness of transglutaminase-mediated polymerisation to restore historic silk was demonstrated.

Keywords: Transglutaminase, Historic silk, Restoration, Ageing behavior

\section{Introduction}

Silk is one of the most significant inventions in the history of human civilisation. Due to the long history of silk culture in China, a large number of valuable and fabulous silk fabrics have been discovered in various ancient tombs [1]. Most of the silk fabrics were made of degummed Bombyx mori silk, which is mainly composed of fibroin. A long time after burial, the condition of most historic silk fabrics is poor; some even turn into powder when touched. Thus, there is an urgent need to develop appropriate conservation techniques to restore the mechanical strength and ensure the long-term preservation of these fabrics.

A wide variety of methods, including weave, mount, silk screen, polymer, and graft copolymerisation [2-7] are commonly and efficiently adopted to consolidate

\footnotetext{
* Correspondence: gdclucky@ustc.edu.cn

'Department of History of Science and Scientific Archaeology, University of Science and Technology of China, Hefei, China

${ }^{2}$ Basic Research Center of Conservation Science, University of Science and Technology of China, Hefei, China
}

historic textiles. Among these, synthetic polymers have been widely used as consolidating agents [8-15] and adhesives [16-19] because of their good mechanical and bonding properties. However, there are some potential problems in the application of synthetic polymers in the conservation and restoration of historic silk. Synthetic polymers are high molecular weight compounds polymerized by low molecular weight monomers, whose molecular structures are quite different from silk protein. Therefore, they are chemically incompatible with silk textiles, and as such, attempts have been made to replace synthetic polymers with protein solutions and cross-linking agents [20-22]. Cross-linking agents often contain multiple functional groups or unsaturated double bonds. Improper cross-linking agents bring potential harm to historic silk as time elapses, considering their corrosion and toxicity. Thus, a more promising method is based on transglutaminase-mediated protein polymerisation as a compatible and innocuous method to reinforce historic silk fabrics.

() Chemistry Central

(c) 2013 Zhu et al.; licensee Chemistry Central Ltd. This is an Open Access article distributed under the terms of the Creative Commons Attribution License (http://creativecommons.org/licenses/by/2.0), which permits unrestricted use, distribution, and reproduction in any medium, provided the original work is properly cited. 
$\mathrm{R}-\mathrm{Glu}-\mathrm{CO}-\mathrm{NH}_{2}+\mathrm{NH}_{2}-\mathrm{Lys}-\mathrm{R}^{\prime} \rightarrow \mathrm{R}-\mathrm{Glu}-\mathrm{CO}-\mathrm{NH}-\mathrm{R}^{\prime}+\mathrm{NH}_{3}$

Figure 1 Reaction formula of transglutaminase-mediated polymerization.

Transglutaminases (EC 2.3.1.13) are a large family of enzymes [23-25] that catalyse a post-translational modification of proteins by forming covalent cross-links between glutamyl and lysyl residues (Figures 1,2). This leads to increased protein stability and resistance to chemical and proteolytic degradation [26]. It has been reported that transglutaminase can mediate sodium caseinate polymerisation to form biopolymers larger than $198 \mathrm{kDa}$ [27]. These biopolymers have been found to significantly improve the tensile strength of sodium caseinate films [28]. As there is no glutamine residue in silk protein, transgluatminase alone has no effect on silk. The addition of sodium caseinate would allow the formation of biopolymers, which could fill in the cracks of silk fibers without harmful agents.

The experimental conditions of transglutaminasemediated restoration of thermal aged silk have been determined by orthogonal experiment [29]. The present study has demonstrated the effectiveness of this reaction to restore historic silk. Due to their rarity and irregular shape, genuine historic silk fabrics were not appropriate for a large number of repeated tests. Instead, artificially aged silk samples were used as substitutes for the restoration experiments. Previous work has demonstrated that dry thermal ageing of modern silk samples under certain conditions can produce both proper residual tensile strength and chemical characteristics similar to that of genuine historic silk [29]. Therefore, the artificially aged samples used here were prepared using the same method. To simulate the conditions of archeological sites, an infrared lamp was used to control the reaction temperature instead of an incubator. The effects of restoration were characterised by means of tensile test, colour difference test, scanning electron microscopy (SEM) and Fourier transform

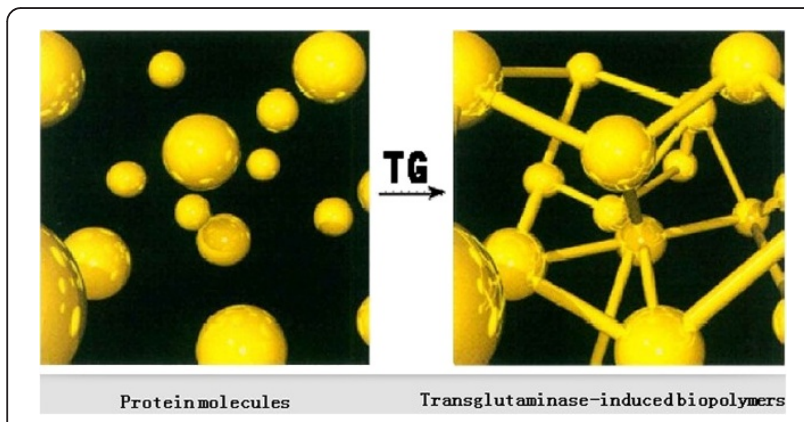

Figure 2 Sketch map of transglutaminase-mediated polymerization.
Table 1 Performance test data of artificially aged samples and restored samples

\begin{tabular}{ccccccc}
\hline & $\begin{array}{c}\text { Tensile } \\
\text { strength } \\
\mathbf{N}\end{array}$ & $\begin{array}{c}\text { Elongation } \\
\text { rate at } \\
\text { breakage\% }\end{array}$ & L & a & b & $\begin{array}{c}\text { Colour } \\
\text { difference }\end{array}$ \\
\hline $\begin{array}{c}\text { Artificially } \\
\text { aged } \\
\text { samples }\end{array}$ & 0.38 & 1.53 & 15.54 & 8.64 & 7.35 & 0 \\
\hline $\begin{array}{c}\text { Restored } \\
\text { samples }\end{array}$ & 2.17 & 4.02 & 15.18 & 8.31 & 6.84 & 0.81 \\
\hline
\end{tabular}

infrared spectroscopy (FT-IR). The ageing resistance of the restored samples was evaluated by standard methods. The method was then applied to genuine historic silk fabrics and achieved the desired results.

\section{Results and discussion Restoration effects}

After restoration, the mechanical properties of the artificially aged samples improved remarkably. As listed in Table 1, the average tensile strength of the artificially aged samples was enhanced from $0.38 \mathrm{~N}$ to $2.17 \mathrm{~N}$ after restoration. The average elongation rate at breakage also increased from 1.53 per cent to 4.02 per cent. This result demonstrated that transglutaminase-mediated polymerisation controlled by infrared lamp proceeded effectively on silk samples. This method is valid for the consolidation of the aged silk samples. In addition, the colour difference caused by restoration was less than 1.00 , which is within the normally acceptable range in the domain of the conservation of historic textiles.

In order to investigate the micro morphology of the artificially aged samples before and after restoration, scanning electron microscope images of the longitudinal section of

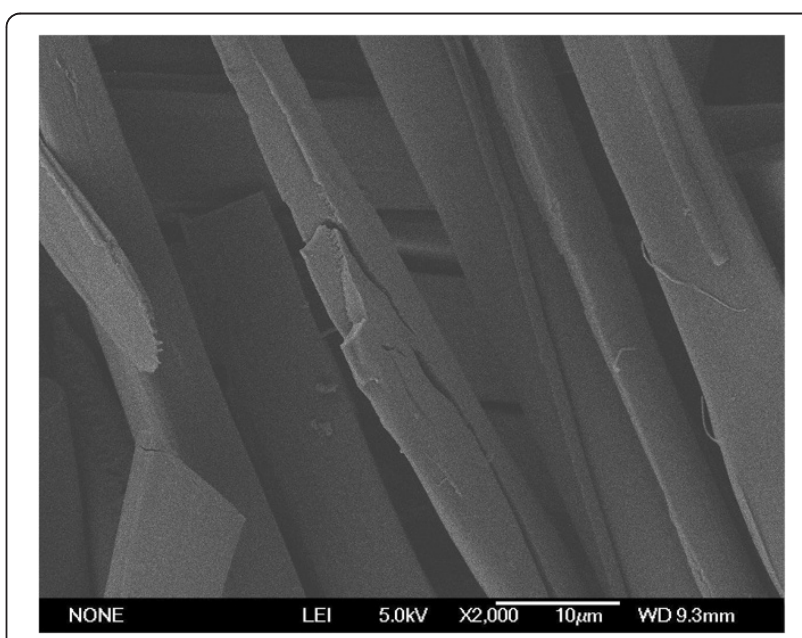

Figure 3 Micro morphology of artificially aged silk sample before restoration. 


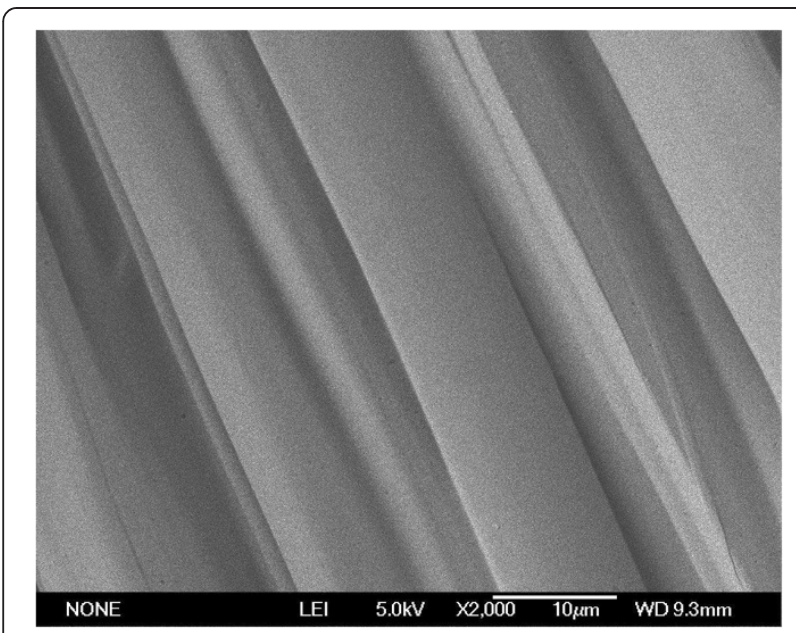

Figure 4 Micro morphology of artificially aged silk sample after restoration.

the samples were observed. As shown in Figures 3, 4, the fibers of artificially aged sample fractured severely; after restoration, the cracks of the fibers were filled with the transglutaminase-induced biopolymers.

ATR FT-IR spectroscopy was applied to confirm the existence of transglutaminase-induced biopolymers in the restored silk samples and analyse their effect on silk protein at the molecular level. The results in Figure 5 show that the main peaks in the fingerprint region $\left(1649.59 \mathrm{~cm}^{-1}\right.$ and $1509.75 \mathrm{~cm}^{-1}$ ) for both samples are nearly the same, which means that the transglutaminase-mediated restoration did not change the basic structure of the silk protein. The characteristic absorption peak of sodium caseinate $\left(1063.47 \mathrm{~cm}^{-1}\right)$ and its transglutaminase-induced biopolymers $\left(1227.11 \mathrm{~cm}^{-1}\right)$ [30] appeared in the spectra of samples after restoration, which proved that the film that enwrapped the silk fibres was composed of transglutaminase-mediated biopolymers.

\section{Ageing resistance}

Ensuring that the treatment would not introduce any long term problems is vital to a novel conservation method. Tensile strength, elongation rate at breakage and colour difference of the artificially aged and restored samples before and after dry thermal and hygrothermal ageing are compared in Tables 2 and 3, respectively. It can be seen that both the mechanical properties and the colour difference of the restored samples changed much less than the artificially aged samples, whether under dry thermal ageing or hygrothermal ageing. This is attributed to the formation of biopolymers of an extremely high molecular weight on the silk fibers in the restoration process. These biopolymers filled in the fractures of the silk fiber and improved the ageing resistance of the silk samples.

\section{Applications on historic silk samples}

Due to a long burial time, historic silk samples excavated from Bailuzhou Cemetery (475 B.C.-221 B.C.) and ZhangAnshi's Cemetery (202 B.C.-9 B.C.) are in poor physical and chemical condition, some even disintegrated when touched. For the purpose of evaluating the restoration effects on genuine historic silk fabrics, transglutaminase-mediated restoration was applied on small samples that wouldn't affect the integrity of historic silk fabrics. It is shown that before restoration, the samples turn easily into powder when flipped gently (Figures 6, 7). After restoration, the enhanced mechanical properties ensure that the samples wouldn't disintegrate when flipped (Figures 8, 9). This shows that

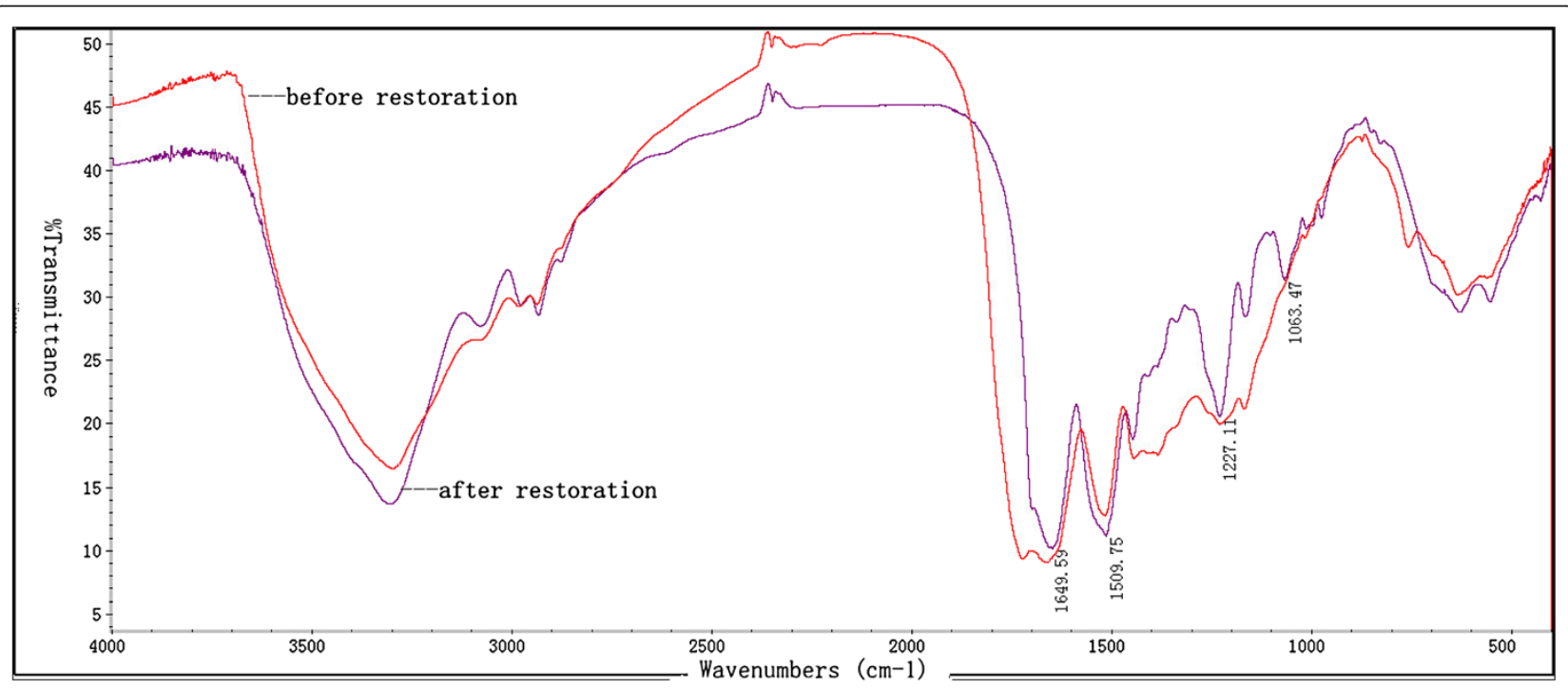

Figure 5 ATR-FTIR spectra of artificially aged silk sample before and after restoration. 
Table 2 Relative tensile properties and colour difference of samples after dry thermal ageing

\begin{tabular}{|c|c|c|c|c|c|c|}
\hline \multirow{2}{*}{$\begin{array}{c}\text { Dry } \\
\text { thermal } \\
\text { ageing } \\
\text { timed }\end{array}$} & \multicolumn{2}{|c|}{ Relative tensile strength $\%$} & \multicolumn{2}{|c|}{ Relative elongation rate at breakage $\%$} & \multicolumn{2}{|c|}{ Colour difference } \\
\hline & $\begin{array}{c}\text { Restored } \\
\text { samples }\end{array}$ & $\begin{array}{l}\text { Artificially aged } \\
\text { samples }\end{array}$ & $\begin{array}{c}\text { Restored } \\
\text { samples }\end{array}$ & $\begin{array}{l}\text { Artificially aged } \\
\text { samples }\end{array}$ & $\begin{array}{c}\text { Restored } \\
\text { samples }\end{array}$ & $\begin{array}{l}\text { Artificially aged } \\
\text { samples }\end{array}$ \\
\hline 0 & 100 & 100 & 100 & 100 & 0.84 & 0 \\
\hline 7 & 96.0 & 76.1 & 94.7 & 75.3 & 0.92 & 0.65 \\
\hline 14 & 89.2 & 63.0 & 86.9 & 61.2 & 1.26 & 1.43 \\
\hline
\end{tabular}

transglutaminase-mediated restoration could restore the mechanical properties of historic silk and ensure long-term preservation.

\section{Experimental \\ Materials}

Plain weaved modern natural silk textiles were purchased from Hefei Guanghua Silk Co. Ltd. Historic silk samples were excavated from Grave M585, Bailuzhou Cemetery (Figure 10) (475 B.C.-221 B.C.), Lu'an City, Anhui Provence and Grave M1, ZhangAnshi's Cemetery (Figure 11) (202 B.C.-9 B.C.), Xi'an City, Shannxi Provence. Infrared lamp (375 W) was purchased from OSRAM Lightbulb Co. Ltd. Transglutaminase was purchased from Beijing Biotopped Science \& Technology Co. Ltd, the measured activity of which was $200 \mathrm{U} \cdot \mathrm{g}^{-1}$. Sodium caseinate was purchased from Sinkiang Kerui Dairy Co. Ltd.

\section{Dry thermal ageing}

Dry thermal ageing was performed according to the method described in reference 29. The purchased natural silk samples were placed on an enamel tray in a forced convection oven, and exposed to a temperature of $230^{\circ} \mathrm{C}$ for 24 hours. Then the silk strips were transferred to a dryer at room temperature. The mechanical properties of the artificially aged samples, genuine historic sample (3000 BP) and non-aged samples are shown in Table 4 [29].

\section{Restoration process}

The artificially aged samples were restored in the following way: A certain amount of sodium caseinate and transglutaminase were dissolved in $0.1 \mathrm{M}$ Tris- $\mathrm{HCl}$ buffer, $\mathrm{pH}$ 7.0, resulting in sodium caseinate concentration being 2 per cent and transglutaminase to sodium caseinate ratio being $30 \mathrm{U} \cdot \mathrm{g}^{-1}$. The obtained mixture was sprayed onto the silk samples; the sample area to mixture volume ratio was $1000 \mathrm{~mm}^{2}: 1 \mathrm{~mL}$. The treated silk samples were then placed under the infrared lamp to keep the samples at $50^{\circ} \mathrm{C}$ for 3 hours.

\section{Tensile properties and colour difference measurements}

The protocol for tensile testing was adapted from BS EN ISO 13934-1:1999 for textile strips. Tensile strength and elongation tests were performed in a PNSHAR PN-TT300 mechanical testing machine, using a $30 \mathrm{~N}$ load cell. Test samples were cut into $100 \mathrm{~mm} \times 15 \mathrm{~mm}$, with the warp along the length. The crosshead rate used in the test was $5 \mathrm{~mm} \cdot \mathrm{min}^{-1}$. Five replicates were analysed for each sample, and the average values were calculated. According to GB/T 8424.2-2001, the colour differences were measured by a PNSHAR PN-48B brightness meter using the diffuse reflectance method. Three replicates were analysed for each sample, and the average values were calculated.

\section{Surface morphology observation}

Scanning electron microscope (SEM) images of samples before and after restoration were observed with a FEI Sirion 200 scanning electron microscope at $5.0 \mathrm{keV}$ accelerating voltage. Samples were mounted on an aluminum stub and sputtered with aurum before being observed.

\section{FT-IR analysis}

ATR FT-IR spectra of samples before and after consolidation were recorded using a Fourier transform infrared spectroscopy (Nicolet 8700, Thermo Scientific Instrument Co. U.S.A) equipped with an ATR attachment. Spectra over the range $4000-400 \mathrm{~cm}^{-1}$ were collected with a resolution of $4 \mathrm{~cm}^{-1}$.

\section{Ageing resistance evaluation}

According to GB/T 24135-2009, dry thermal ageing (70) and hygrothermal ageing $(70, \mathrm{RH}=90 \%)$ of samples

Table 3 Relative tensile properties and colour difference of samples after hygrothermal ageing

\begin{tabular}{|c|c|c|c|c|c|c|}
\hline \multirow{2}{*}{$\begin{array}{l}\text { Hygrothermal } \\
\text { ageing timed }\end{array}$} & \multicolumn{2}{|c|}{ Relative tensile strength \% } & \multicolumn{2}{|c|}{ Relative elongation rate at breakage \% } & \multicolumn{2}{|c|}{ Colour difference } \\
\hline & $\begin{array}{c}\text { Restored } \\
\text { samples }\end{array}$ & $\begin{array}{l}\text { Artificially aged } \\
\text { samples }\end{array}$ & $\begin{array}{c}\text { Restored } \\
\text { samples }\end{array}$ & $\begin{array}{l}\text { Artificially aged } \\
\text { samples }\end{array}$ & $\begin{array}{c}\text { Restored } \\
\text { samples }\end{array}$ & $\begin{array}{c}\text { Artificially aged } \\
\text { samples }\end{array}$ \\
\hline 0 & 100 & 100 & 100 & 100 & 0.84 & 0 \\
\hline 7 & 90.6 & 63.4 & 89.7 & 62.1 & 0.96 & 0.77 \\
\hline 14 & 79.5 & 0 & 78.3 & 0 & 1.33 & 1.64 \\
\hline
\end{tabular}




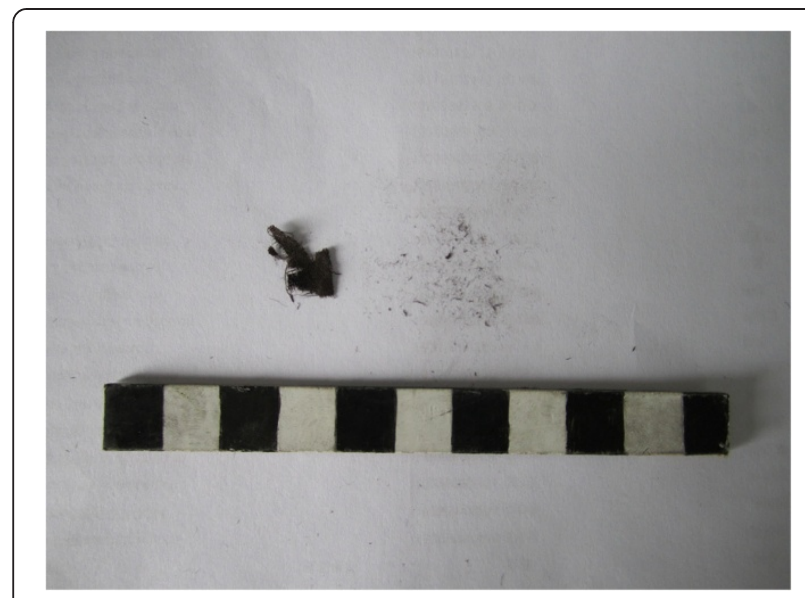

Figure 6 Appearance of historic silk sample excavated from Bailuzhou Cemetery before restoration.

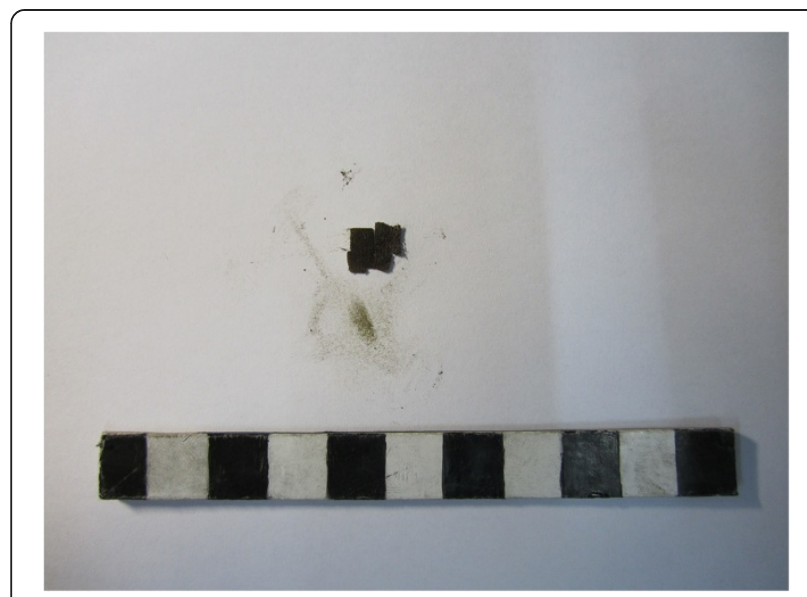

Figure 7 Appearance of historic silk sample excavated from ZhangAnshi's Cemetery before restoration.

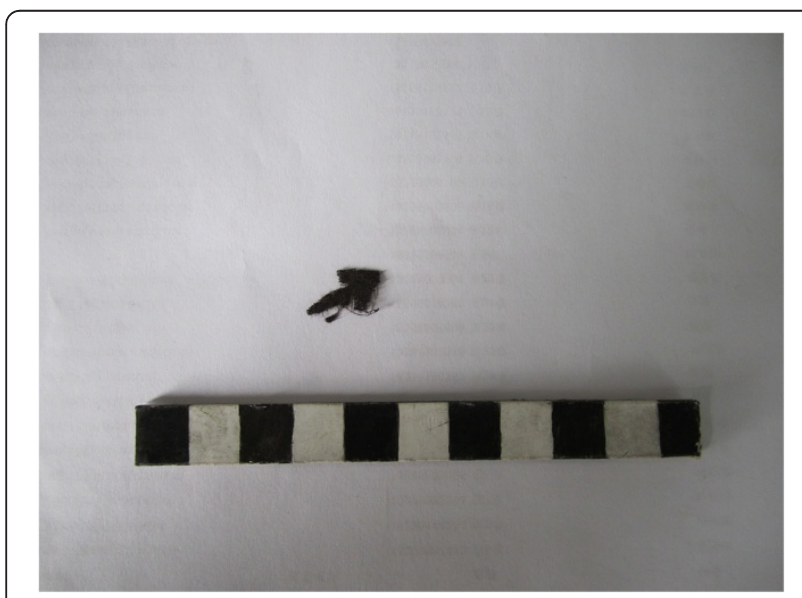

Figure 8 Appearance of historic silk sample excavated from Bailuzhou Cemetery after restoration.

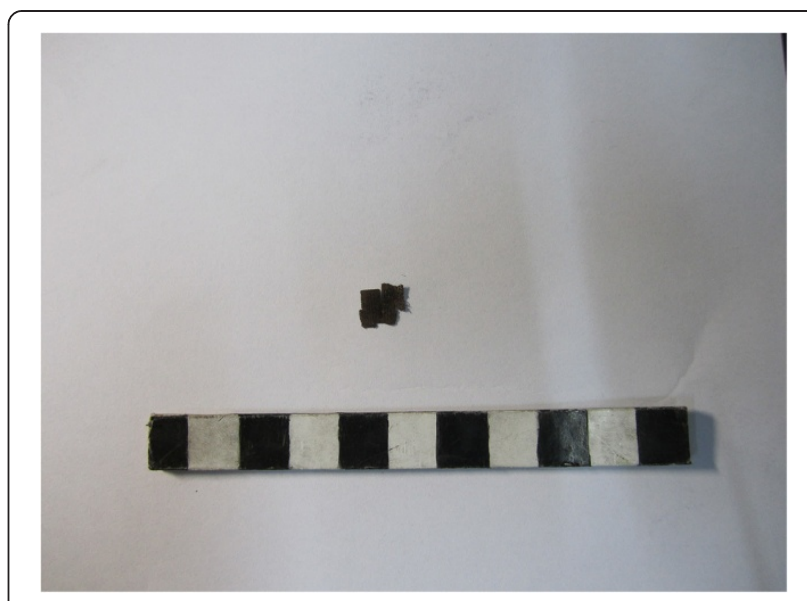

Figure 9 Appearance of historic silk sample excavated from ZhangAnshi's Cemetery after restoration.

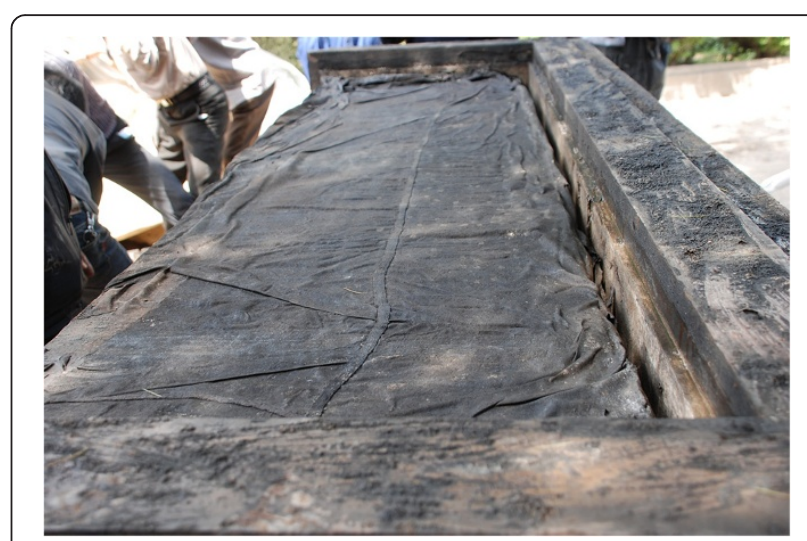

Figure 10 Historic silk textiles excavated from Grave M585, Bailuzhou Cemetery (475 B.C.-221 B.C.), Lu'an City, Anhui Provence.

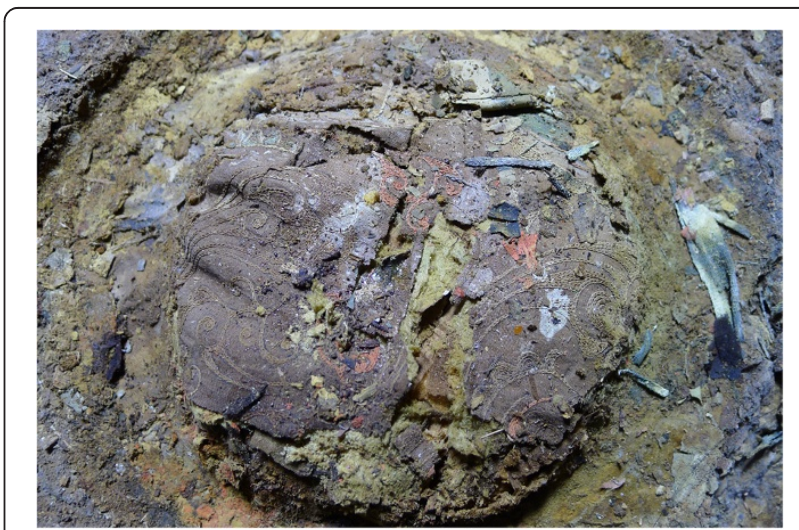

Figure 11 Historic silk textiles excavated from Grave M1, ZhangAnshi's Cemetery (202 B.C.-9 B.C.), Xi'an City, Shannxi Provence. 
Table 4 Mechanical properties of artificially aged samples, genuine historic sample (3000 BP) and nonaged samples

\begin{tabular}{lccc}
\hline $\begin{array}{l}\text { Mechanical } \\
\text { properties }\end{array}$ & $\begin{array}{c}\text { Artificially aged } \\
\text { samples }\end{array}$ & $\begin{array}{c}\text { Genuine } \\
\text { historic sample }\end{array}$ & $\begin{array}{c}\text { Non aged } \\
\text { samples }\end{array}$ \\
\hline Tensile strength(N) & 0.38 & 0.41 & 282.75 \\
\hline $\begin{array}{l}\text { Elongation rate at } \\
\text { breakage(\%) }\end{array}$ & 1.53 & 1.57 & 12.65 \\
\hline
\end{tabular}

before and after restoration were carried out by placing samples on an enamel tray in a artificial climate chamber for 7 and $14 \mathrm{~d}$, respectively. Then, the samples were cooled at room temperature for at least $18 \mathrm{~h}$ before testing. The tensile properties (tensile strength and elongation at break) and colour difference of aged samples were determined in the same manner as previously mentioned. Relative tensile properties were employed to represent the thermal ageing resistance of samples. They were calculated using the following equation:

Relative tensile properties $=\frac{\mathrm{T}_{\mathrm{aged}}}{\mathrm{T}_{\text {unaged }}} \times 100 \%$

where $T_{\text {aged }}$ and $T_{\text {unaged }}$ are tensile properties of aged and unaged samples, respectively.

\section{Applications on historic silk samples}

Fragile historic silk samples excavated from Bailuzhou Cemetery (475 B.C.-221 B.C.) and ZhangAnshi's Cemetery (202 B.C.-9 B.C.) were restored by the same process as artificially aged samples. The effects of restoration were evaluated by apparent phenomena.

\section{Conclusions}

As a compatible and innocuous consolidation method, transglutaminase-mediated restoration was adapted to meet the requirements of reinforcing fragile historic silk fabrics at archaeological sites. The mechanical properties of the fabrics were improved substantially without an obvious change in the appearance of the samples. The fractures in the fibers were filled by the biopolymers which were modified by transglutaminasemediated polymerisation. The good ageing resistance of the restored samples proved that this method will stabilize historic silk over a long period of time. Therefore, transglutaminase-mediated polymerisation is an effective strategy for the restoration of historic silk.

\section{Competing interests}

The authors declare that they have no competing interests.

\section{Authors' contributions}

DG conceived of the study, and participated in its design. ZY performed the restoration process, tensile properties and colour difference measurements, and also drafted the manuscript. LL performed the surface morphology observation, ageing resistance evaluation. The analyses and statistical interpretation were carried out together by all authors. All authors read and approved the final manuscript.

\section{Acknowledgements}

Financial support from the Key Projects in the National Science \& Technology Pillar Program of China during the 11th Five-Year Plan period (2010BAK67B13) is gratefully acknowledged.

Received: 30 January 2013 Accepted: 7 March 2013

Published: 16 April 2013

\section{References}

1. Gong DC: The research on contaminating and cleaning of historic silks. PhD Thesis. University of Science and Technology Beijing: Department of the History of Metallurgy and Materials; 2006.

2. Abdel-Kareem OMA: The long-term effect of selected conservation materials used in the treatment of museum artefacts on some properties of textiles. Polym Degrad Stab 2005, 87(1):121-130.

3. Wang HZ: The Conservation of cultural relics. Beijing: Cultural Relics Publishing House; 2009.

4. Institute of Chinese Cultural Heritage: Conservation and restoration of Chinese cultural heritages. Beijing: Science Press; 2009.

5. Identification and Conservation Center of Chinese Textiles: Introduction of identification and conservation of textile. Beijing: Cultural Relics Publishing House; 2002.

6. Zhang $\mathrm{XL}$, Tang JJ: Reinforcing and preserving of ancient silk fabrics. Sciences of Conservation and Archaeology 1999, 11(1):23-30.

7. Zhang XM, Yuan SX: The application of a new kind of silicone modified acrylic resin for the consolidation of fragile silk fabrics. Sciences of Conservation and Archaeology 2003, 15(2):1-9.

8. Coccaa M, D'Arienzo L, D'Orazio L, Gentile G, Mancarella C, Martuscelli E, Polcaro C: Water dispersed polymers for textile conservation: A molecular, thermal, structural, mechanical and optical characterization. J Cult Herit 2006, 7(4):236-243.

9. D'Arienzo L, Gentile G, Martuscelli E, Polcaro C, D'Orazio L: Acrylic and acetovinylic polymers for preserving and restoring cotton textiles. Text Res J 2004, 74(4):281-291.

10. Gill K, Boersma F: Solvent reactivation of hydroxypropyl cellulose (Klucel $\mathrm{G}^{\circledR}$ ) in textile conservation: Recent developments. The Conservator 1997, 21(1):12-20.

11. Sato M, Okubayashi S, Sato M: Development of conservation procedures for late Edo period Japanese ceremonial dolls' hair: Evaluation of effective treating reagents by using artificially degraded black-dyed silk fibres. J Cult Herit 2011, 12(2):157-163.

12. Moe S, Satoko O: Consolidation treatment of Japanese ceremonial doll's Hair at Edo period with polyethylene glycol. J Text Eng 2010, 56(3):65-70

13. Abdel-Kareem O, Zidan Y, Lokma N, Ahmed H: Conservation of a rare painted ancient Egyptian textile object from the Egyptian Museum in Cairo. e-Preservation Science 2008, 5:9-16.

14. Halvorson B, Kerr N: Effect of Parylene C on selected properties of silk. In Silk: Harper's Ferry Regional Textile Group, November 12-13, 1992, National Museum of American History. Harper's Ferry Regional Textile Group. (Corporate Author). Harpers Ferry Regional Textile Group, Harpers Ferry, West Virginia; 1993:73-77 [English w. English summaries].

15. Halvorson B, Kerr N: Effect of light on the properties of silk fabrics coated with parylene-C. Stud Conserv 1994, 39(1):45-56

16. Ragauskienè D, Makuška R: Consolidation and ageing features of vinylneodecanoate containing in adhesive films used as a support for museum textiles. CHEMIJA 2006, 17(2-3):52-59.

17. Hillyer $L$, Tinker $Z$, Singer P: Evaluating the use of adhesives in textile conservation: Part 1: An overview and surveys of current use. The Conservator 1997, 21(1):37-47

18. Verdu J, Bellenger $\mathrm{V}$, Kleitz MO: Adhesives for the consolidation of textiles. In Adhesives and consolidants: preprints of the contributions to the Paris Congress, 2-8 September 1984. Edited by Brommelle NS. London, United Kingdom: International Institute for Conservation of Historic and Artistic Works; 1984:64-69 [English].

19. Masschelein-Kleiner L, Bergiers F: Influence of adhesives on the conservation of textiles. In Adhesives and consolidants: preprints of the contributions to the Paris Congress, 2-8 September 1984. Edited by Brommelle 
NS. London, United Kingdom: International Institute for Conservation of Historic and Artistic Works; 1984:70-73 [English].

20. Zhou Y, Zheng HL, Hu ZW, Zhao F: Research on the use of fibroin protein for consolidation of ancient silk textiles. Sciences of Conservation and Archaeology 2010, 22(3):44-48.

21. Zhang J, Peng ZQ, Hu ZW, Huang D, Qin DY, Zhao F, Zhou Y: The consolidation effect of L-Cys/EGDE to hydrolysis-aged and light-aged silk fabrics. Science of Sericulture 2011, 37(5):847-852.

22. Hu ZW, Huang XF, Zhang J, Cao XY, Zheng HL, Zhou Y, Zhao F, Peng ZQ: Reinforcement of silk fibroin/ethylene glycol diglycidyl ether on the aging of silk fibres. Polymer Materials Science and Engineering 2011, 27(12):44-47.

23. Nielsen PM: Reactions and potential industrial applications of transglutaminase: Review of literature and patents. Food Biotechnol 1995, 9(3):119-156.

24. Zhu Y, Rinzema A, Tramper J, Bol J: Microbial transglutaminase: A review of its production and application in food processing. Appl Microbiol Biotechnol 1995, 44:277-282.

25. Griffin M, Casadio R, Bergamini C, Transglutaminases: Nature's biological glues. Biochem J 2002, 368:377-396.

26. Mehta K, Rao R, Chandrashekar R: Transglutaminases of the lower organisms. Minerva Biotechnology 2002, 14(2):129-134.

27. Myllarinen P, Buchert J, Autio K: Effect of transglutaminase on rheological properties and microstructure of chemically acidified sodium caseinate gels. Int Dairy J 2007, 17:800-807.

28. Jiang $Y$, Tang $\mathrm{CH}$, Wen $\mathrm{QB}$, Yang $\mathrm{XQ}$ : Effects of transglutaminase on properties of edible films from soybean protein isolates, sodium caseinate and gelatin. Chemical Industry and Engineering Progress 2006, 25(3):324-328

29. Zhu ZY, Gong DC: Determination of the experimental conditions of the transglutaminase-mediated restoration of thermal aged silk by orthogonal experiment. J Cult Herit. in press.

30. Tang CH: Study on enzymatic polymerization of food proteins and mechanism of its modification. PhD Thesis. South China University of Technology: Department of Food Science \& Bioengineering; 2002.

doi:10.1186/2050-7445-1-13

Cite this article as: Zhu et al:: Transglutaminase-mediated restoration of historic silk and its ageing resistance. Heritage Science 2013 1:13.

\section{Publish with ChemistryCentral and every scientist can read your work free of charge \\ "Open access provides opportunities to our colleagues in other parts of the globe, by allowing anyone to view the content free of charge." \\ W. Jeffery Hurst, The Hershey Company. \\ - available free of charge to the entire scientific community \\ - peer reviewed and published immediately upon acceptance \\ - cited in PubMed and archived on PubMed Central \\ - yours - you keep the copyright \\ Submit your manuscript here: \\ http://www.chemistrycentral.com/manuscript/<smiles>c1ccccc1</smiles> 